"The environmental and economic implications of the climate change and extractive industry nexus in Africa"

AUTHORS

ARTICLE INFO

DOI

RELEASED ON

JOURNAL

FOUNDER

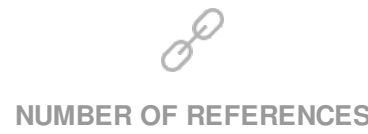

0
Ademola Oluborode Jegede

Ademola Oluborode Jegede (2016). The environmental and economic implications of the climate change and extractive industry nexus in Africa. Environmental Economics, 7(4-1), 95-103. doi:10.21511/ee.07(4-1).2016.01

http://dx.doi.org/10.21511/ee.07(4-1).2016.01

Wednesday, 21 December 2016

"Environmental Economics"

LLC "Consulting Publishing Company "Business Perspectives"

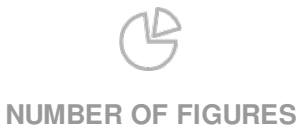

0
NUMBER OF TABLES

0

(C) The author(s) 2023. This publication is an open access article. 
Ademola Oluborode Jegede (South Africa)

\title{
The environmental and economic implications of the climate change and extractive industry nexus in Africa
}

\begin{abstract}
Climate change and extractive industry are two important global streams that are linked to each other in that risks associated with the former can adversely affect different areas of the extractive sector, while the activities of the latter can contribute to climate change. Yet, this nexus is hardly clearly articulated in the context of implications for the environment and economic considerations in Africa. Assessing key literature on the two themes, the paper argues that the link of extractive industry with climate change can have both negative and positive implications for environmental protection and the economy in Africa. The nexus of climate change and the extractive sector can be negative in that unsustainable extractive processes in terms of their outcome of deforestation and energy use are an important source of carbon emission contributing to global warming. The nexus can be positive in that it involves initiatives that can contribute to sustainable extractive sector and thereby reduce carbon emissions underlying climate change.
\end{abstract}

Keywords: Africa, climate change, extractive sector, environmental protection, economic implications.

JEL Classification: Q51, Q58, N5.

\section{Introduction}

Climate change, according to the Preamble of the Paris Agreement $(2015)^{1}$ and Goal No. 13 of the United Nations Sustainable Development Goals $(2015),{ }^{2}$ is a global concern due to its adverse effects on mankind. Regarding Africa, Nang et al. (2014), like many other authors (Toulmin, 2009, p. 77; Collier et al., 2008) note that climate change and related hazards are projected to rise in degree, but, the nexus of climate change and extractive industry, and more importantly, their implications for the protection of the environment and economic development are not explored. Yet, decades of increasing discussion on a changing climate have been noted for growing global interest in the extractive industry, that is, activities associated with the extraction of raw materials such as oil, metals and minerals from the earth for processing and production in Africa (Horsley et al., 2015, p. 368; Fischedick et al., 2014, p. 747). Reviewing the existing key literature on the themes, this paper argues that the nexus of climate change and the extractive industries can have both negative and positive implications for environmental protection and the economy in Africa.

(C) Ademola Oluborode Jegede, 2016

Ademola Oluborode Jegede, LLD, BL, Senior Lecturer, Public and International Law, University of Venda, Thohoyandou, South Africa.

${ }^{1}$ Paris Agreement under the United Nations Framework Convention on Climate Change 2015, adopted by Conference of the Parties, 21st Session Paris, 30 November to 11 December 2015. FCCC/CP/2015/L.9/Rev.1.

2 It is one of the goals that form a part of the 17 Sustainable Development Goals (SDGs) to end poverty, fight inequality and injustice, and tackle climate change by 2030 , adopted by World Leaders at the United Nations Sustainable Development Summit on 25 September 2015; see generally UNDP Sustainable Development Goals.

\section{The nexus of climate change and extractive industry in Africa}

Defined as the long term weather condition of a region and its pattern of change over time, literature explains the causation of climate change as arising from the warming of the earth due to the contribution of emission arising from human activities to greenhouse gases (GHG) which alters the natural greenhouse effect (IPCC, 2013, pp. 8-15; Gore, 2006; Kheshgi et al., 2005, pp. 213-214). The emission is linked to fossil fuel burning which supports the economic sector consisting of industry, automobiles and the energy demands of modern day, and other related activities (Jegede, 2016, p. 2; Gore, ibid; Pearce, 2011, p. 347). While it is not every impact of climate change that is adverse, evidence of harmful consequences is recorded across Africa (Niang et al., 2014, p. 1202), despite the fact that the continent contributes little to its cause (Toulmin, 2009, p. 77; AfDB, 2008, p. 45). In general terms, the vulnerable sectors to climate change of environmental and economic importance in Africa are water resources, food security, natural resource management and biodiversity, human health, settlements and infrastructure (Niang et al., 2014, pp. 433-467).

The above is more so as the era of changing climate is noted for an unprecedented growth in the extractive sector in Africa. For instance, studies have shown that increasing national revenues are derived from natural resources in countries such as Botswana (Besada, 2013, p. 34), Ghana (ArmahAttoh, 2015), and Zambia (Stevens, 2015). In Tanzania, mining activities have created a multitude of income opportunities for inhabitants of resource rich areas (Stevens, 2015). In relation to metallic minerals, Kelly and Matos (2013, p. 140) 
reported that from 2005 to 2012, the annual global production of iron ore, gold, silver, and copper increased by $10 \%, 1 \%, 2 \%$, and $2 \%$, respectively. This growth is largely driven since 2008 by consumption in China, India, and developed countries (Santi and Wiegert, 2015; UNCTAD, 2008, p. 294). As UNCTAD (ibid) reported, China imported 50\% of the world's total iron ore exports and produced about $50 \%$ of the world's pig iron, in 2008 alone. The same report indicated that India demanded $35 \%$ of world's total gold production in 2011, while the United States of America consumed $33 \%$ of world's total silver production in 2011 (Ibid). More recent evidence, in particular, show that the economy of Africa has been in the supply chain. For example, there has been a marked increase in mining activities in Zambia (Sikamo et al., 2016, p. 491), South Africa (Neingo and Tholana, 2016) and Botswana (UNDP, 2015). According to Bach (2014), there is a sharp increase in gold and bauxite mine in Ghana, while Rwanda's mineral industry has been producing gold ores and other minerals including columbium, tantalum, tin and tungsten for export (van Teeffelen, 2012). Generally, Mailey (2015) reported that oil producing states in the Sub-Saharan Africa have grown to 10 countries, while promising discoveries have been made in new states including Kenya, Madagascar, Sierra Leone, Mozambique, Tanzania and Uganda. Furthermore, Rudel (2013, p. 1) noted that the Congo basin countries such as Cameroon, Central African Republic, the Congo, the DRC, Equatorial Guinea and Gabon remain vital sources of minerals including copper, cobalt, diamonds, platinum, gold, oil and gas.

Climate change links to the extractive industry in the sense that hazards associated with it such as high precipitation levels, flooding, windstorms, erosion, and extremes in temperature will adversely affect different areas of mining sector, namely, the inputs of water and energy, people, supply chains, markets, exploration, construction, operation, closure, and post-closure (International Council of Mining and Metals, 2013, p. 14), and arguably undermine economic growth. Locke et al. (2011) find that greater intensity and/or frequency of storms associated with flooding and changes in waterbeds are linked to closure of mining activities. Climate change will affect exploration, extraction of mining and quarrying (Arent et al., 2014). Extreme conditions such as rising temperature, flooding, stronger wind, frequency of precipitation will weaken structural integrity, bridges, pipelines, and walls thereby compromizing accessibility of mining sites and safety in operations (Boyle, 2013). As Ford et al. (2010, p. 65) found, hazards such as forest fires resulting from heat waves and other risks will affect accessibility and thereby reduce the viability of mining operations.

Similarly, evidence of nexus of climate change with the extractive industry exists in the sense that climate related risks are affecting the viability of the extractive sector which may undermine economic development in Africa. For instance, extremes in temperature and associated events such as flooding are regular features in the frequency and duration of cholera outbreaks in African states with mining intensive activities, such as Ghana, Senegal, other coastal West African countries, and South Africa (AfDB, 2014). This development compounds the health and safety of workers in the mining sector which is already confronted with grave environmental challenges (WHO, 2014; Reyburn, 2011, p. 862). In particular, as Nweke and Sanders (2009, p. 863) found, workers in the mining sector in states including Tanzania, Ghana, Zambia and Zimbabwe are exposed to serious environmental health hazards resulting from exposure to mercury and lead associated with mining which can endanger their vital organs including the kidneys, the cardiovascular and immune systems and, thus, slow down their contribution in a sector at the heart of the African economy.

Water and energy are critical inputs to mining operations for dust suppression, product separation and crushing, concentrate and waste transport, and further processing (Ranchord et al., 2015; ICMM, 2012 , p. 7). In Africa, climate change will worsen water scarcity which, as predicted, will increase to 65 per cent in 2025, affecting countries in Eastern and Southern Africa (Niang et al., 2014; Toulmin, 2009). Also it will compound the situation in states in Northern Africa including Algeria, Egypt, Libya, Morocco, Western Sahara, and Tunisia where increasing desertification is projected (Faour et al., 2016; Toulmin, 2009, p. 40). The implication for the extractive sector in Africa is that a limited availability of water will constrain the access of mining companies to sufficient supply of water for operations and production. Climate change also adversely affects the supply chain of the extractive industry in that operations require effective transport and coastal port facilities which are vulnerable to disruption such as sea level rise, flooding and storms associated with climate change (Turner, 2014; ICMM, 2012, p. 17). Findings show that climate change has negative effect for coastal potentials for trade in different regions of Africa (USAID, 2013). Arguably, this trend will impact supply chain and trade in extractive materials and may slow down economic development in Africa. 
A changing climate affects market for goods and products from the extractive sector. For example, the need to address climate change may reduce the demand profile for metals and minerals from carbon intensive mining activities. As Aguado (2011, p. 5) and SASB (2014) observe, the possibility is emerging that developed states may apply trade measures such as carbon tariffs or border restriction on carbon-intensive minerals of developing countries including Africa. In relation to construction and operations, risks associated with climate change will challenge construction infrastructure constructed without a changing climate in perspective (Ford et al., ibid). Also a changing climate will affect ground temperature and weaken mining structure, thereby encourage closure and post closure activities in Africa (Ndlovu, 2016).

What then are the implications of the nexus of climate change and the extractive sector for environmental protection and the economy in Africa? It is argued that the link of extractive industry with climate change can have both negative and positive implications for environmental protection and the development of the economy in Africa.

\section{Negative effects of the climate change and extractive nexus for the environmental and economic sector}

The extractive industry is an engine of economic growth, but it is also a catalyst of climate change and, as a result, can compromize environmental standard. Since the publication of 'The resource curse thesis' by Auty (2002), for instance, there has been a growing body of evidence reinforcing the view that in terms of the protection of the environment, 'favorable natural resource endowment may be less beneficial to countries at low- and mid-income levels of development than the conventional wisdom might suppose'. This is not surprising considering that a significant feature of the 'curse thesis' is environmental degradation due to activities involved in harnessing the natural resources (Ploeg, 2011, p. 366), which arguably contribute to climate change and the economy in Africa.

The negative impacts of the extractive sector on climate change are best explored through the implications for climate change of environmental degradation associated with the forest-related mining activities. For example, while coal and oil are resources of great economic value to Africa, unsustainable mining of coal and oil often involves the clearance of large areas of forest where the resources are located, thus, resulting in deforestation. The foregoing has implications for climate change, because when a forest is cleared, scientific research has shown that it releases stored carbon into the atmosphere and, thus, becomes a source of GHG emissions, which alters the natural greenhouse effect (Gorte and Sheikh, 2010; Helmut and Lambin, 2001). In Africa, evidence from Hironsa (2015, p. 2) and Cotula (2012, p. 649) show that diminishing forest cover has been a feature of the mineralization of Sub-Saharan African economies. Literature is replete with examples of unsustainable practices in mining and deforestation in the six Congobasin areas (Doetinchem et al., 2013), Equatorial Guinea and Gabon (Rudel, 2013, p. 45), and Zambia (Horsely, 2015, p. 368). Economy-focused activities including oil drilling and exploration such as the establishment of roads, drilling of pipelines, other infrastructural development, and settlement of workers involve the clearing of forests in tropical countries such as Nigeria, Gabon and Cameroon (Jegede, 2016, pp. 13, 25; Oluduro, 2014; Wunder, 2005). Similarly, in Southern Africa, according to King (2014), a broad area of formerly intact natural vegetation is giving in to extractive purposes for economic development, and evidence suggesting that emission related to deforestation is associated with oil exploration. In all, the foregoing signifies that though natural resources are central to the economy of Africa, there is potential in degradation and emission associated with mining activities in Africa to contribute to climate change and, therefore, undermines healthy environment.

The extractive sector is equally of importance to climate change, because it entails energy intensive activities that are significant sources of carbon emission (Heinberg, 2015). These activities which are focused on economic development include excavation, mine operation, material transfer, mineral preparation and separation (Fischedick et al., p. 747), as well as the transformation of materials into refined products and closure activities such as incineration of waste, which leads to further carbon emissions. Emissions arising from energy use in the extractive sector constitute over $30 \%$ of the global GHG emissions including direct energyrelated carbon emission and indirect carbon emissions from production of electricity and heat for the industry (Fischedick, p. 748). Carbon emission from energy is low compared to other regions, but coal-related energy use in mining and heavy industry is a driver of economic development in South Africa (Alton et al., 2014, p. 344), accounting for $38 \%$ of the continental total, while states, namely, Egypt, Algeria, Nigeria, Libya and Morocco combined take 46\% (Boden et al., 2011). 
The increasing energy consumption associated with the extractive sector in Africa contributes its shares of impact on the global emission profile. Despite the foregoing, there are positive effects in the nexus of climate change and the extractive industry for both the protection of the environment and economic development.

\section{Positive effects of the climate change and extractive industry nexus for the environment and economy}

Climate change nexus with the extractive industry through its response measures, and the shift of global attention to the notion of green economy, which aims at industrialization through the sustainable management of the extractive sector have positive implications for both the economy and the protection of the environment in Africa. This proposition is agued below.

\section{Climate response measures can motivate sustainable mining}

Climate response measures are well defined in a number of climate related instruments. For instance, according to Article 4 of the United Nations Framework Convention on Climate Change (1992), ${ }^{3}$ adaptation and mitigation are the two global responses to adverse climate change. While adaptation is the response that moderates harm or exploits beneficial opportunities in climate change, mitigation refers to human intervention to reduce the sources or enhance the sinks of GHG (Klein, 2007, pp. 745-747). Examples of these measures include projects promoting renewable sources of energy under Article 2, paragraph 1(a)(iv) of the Kyoto Protocol (Tauli-Corpuz, 2007, p. 52). ${ }^{4}$ These projects and measures are featuring in economy-related discussions of states in Africa. For instance, states like Kenya, Tanzania, Namibia and Ethiopia participate in projects dealing with biofuel plantations aimed at enhancing alternative energy use (Vermeulen and Cotula, 2010, p. 899). Other examples of response measures include REDD+ (den en Besten, 2014, p. 40) and initiatives under the Clean Development Mechanism (CDM) endorsed by Article 12 of the Kyoto Protocol (1995), now replaced by the new Sustainable Development Mechanism under Article 6(4) of the Paris Agreement (2015).

The REDD+ stands not only for reducing emissions from deforestation and forest degradation, but also incentivising conservation, sustainable management of forests and enhancement of forests as stocks of carbons in developing countries (den en Besten, 2014, p. 40).

\footnotetext{
United Nations Framework Convention on Climate Change (UNFCCC), ILM 851, adopted in 1992.

4 United Nations Kyoto Protocol to the United Nations Framework Convention on Climate Change (1998), entered into force 16 February 2005.
}

States that are fully under REDD+ include DRC, Nigeria, Tanzania, Zambia, and targeted efforts are supported in Benin, Cameroon, the Central African Republic, Côte d'Ivoire, Ethiopia, Ghana, Kenya, Madagascar, Morocco, South Sudan, the Sudan, Tunisia and Uganda (UNREDD Website). The CDM promotes sustainable development initiatives such as reforestation and alternative sources of energy in developing countries, including Africa (UNFCCC CDM Website).

In aiming at the promotion of alternative sources of energy and avoidance of deforestation, the above projects can contribute to the sustainable growth of the extractive industry and thereby positively impact on the protection of the environment and the economy. For instance, the development of alternative sources of energy can reduce carbon emissions and enhance mining that is climate friendly in Africa. Also, projects such as reforestation and afforestation which are linked to environmental protection may result from climate change and extractive industry nexus. This is not only as Hirons et al. (2014, p. 430) argue that they can form part of the closure and post closure activities of the mining operation, it is also because their accommodation in mining operation design can serve the use of assessing seriousness of government to prevent environmental harm. Similarly, the fact that the REDD+ initiative can help to prevent exploration of forests rich in natural resources can help to reduce over-reliance on the extractive sector and thereby guarantees the sustainable use of non-renewable resources for the present and future generation.

\section{Green economy can enhance natural resource efficiency}

Defined as an economy that can 'result in improved human well-being and social equity, while significantly reducing environmental risks and ecological scarcities' (UNEP, 2011), the idea of green economy uniquely suggests that the extractive industry can be engaged in a manner that enhances the protection of environment and, therefore, reduces emission which contributes to climate change. The notion of green economy became popular in world stage during the Rio+20 Conference, where it was projected as a replacement to the notion of sustainable development (Ulrich, 2012 , p. 28). ${ }^{5}$ It was adjudged that the notion of sustainable development has become discredited in the light of absence of will of states and other actors to push the strategy (Ulrich, ibid). Evidence of its loss of appeal is found not only in the unsustainable use of resources and ecosystems which continue to increase since the emergence of the notion (Haberl

\footnotetext{
5 The United Nations Conference on Sustainable Development - or Rio+20 - took place in Rio de Janeiro, Brazil on 20-22 June 2012, see https://sustainabledevelopment.un.org/rio20 (accessed 27 October 2016).
} 
et al., 2011, p. 1). It is also in the fact that emissions of carbon continue to constrain the ability of the natural systems to cope (Kosoy et al., 2012, p. 74). It is equally visible in the fact that human kind continues to treat nature as a commodity that exists largely for the benefit of people, under the wrong assumption that all environmental problems can be solved through the deployment of appropriate technology (Kosoy et al., ibid).

The concept of green economy, thus, emerges as an attempt to depart from business as usual approach. Through an emphasis on low carbon, resource efficient, and public and private investments that reduce carbon emissions and pollution, Acosia (2015) notes that in enhancing energy and resource efficiency, the notion of green economy can prevent the loss of biodiversity and ecosystem services. The notion can prevent the focus on the over-use of nonrenewable natural resources which essentially form the extractive sector, promote better management of natural resources and thereby limit carbon imprint of involved activities on the climate.

That the above possibility is feasible in Africa is not difficult to imagine. Sustainable management of natural assets has been suggested as a key feature of green growth and resilience to natural disaster and climate change effects in Africa (AfDB, 2013). This is not unexpected, considering the environmental risks that the exploration of resources has occasioned in different states in Africa. Exploration of mineral resources cause significant environmental degradation, as discernible from Nigeria where flaring emissions are high (Oluduro, 2014, p. 214), and shale gas fracking being prospected in South Africa is projected without due consideration to environmental impact (Perrot, 2012). Hence, focusing on sustainable management of these resources will reduce emissions of carbon, which are in themselves dangerous to the extractive sector and the climate. It will reduce unnecessary dependence on the sector by shifting attention to additional renewable resources to complement the extractive sector (ECA, 2012), and thereby help in reducing resource use in a manner that compromizes the environment in Africa.

It is not surprising that states including Mauritius, the Seychelles, Rwanda, Kenya, Mozambique, Ethiopia and South Africa are preparing to take full advantage of green economy (Nhamo, 2013, p. 115). In particular, Rwanda Vision 2050 envisages the development of a climate-resilient, low-carbon economy that rests on pillars including sustainable land use management and climate compatible mining. On the condition that funding and technological support be provided by international mechanisms, South Africa has committed itself to a path that would see emissions reduced by 34 per cent by 2020 , and by 42 per cent by 2025 . In addition to the notion of green economy which spotlights natural resource efficiency, another emerging mechanism for environmental protection which is associated to climate change and the extractive industry is carbon tax.

\section{Carbon tax can reduce emissions associated with extractive sector}

Carbon tax is connected with the extractive industry and of implication for environmental protection, because it aims at addressing the emissions of $\mathrm{GHG}$ associated with the combustion of coal, gas and oil underlying global warming. It refers to a tax on the carbon content of fuels (WTO, 2010, p. 5). A carbon tax has been shown as an effective option for reducing GHG emissions (Fernandez, 2015). On its social implications, however, opinions of writers are polarized. Some authors find that carbon tax is an efficient tax instrument for energy use or pollution management (Alton et al., 2014, p. 344; Yue-Jun and Yi-Ming, 2010, p. 1804), while other authors argue that carbon taxes may bring about increase in the prices of energy and energy-intensive goods, and hurt the poor of the society (Maron, 2016). Winkler and Marquard (2011, p. 55) contend that revenues generated from carbon tax can be used by government in a progressive manner that encourages sustainable use of energy and off-set the potential effects of higher energy prices on the poor.

Carbon tax is not yet popular in the tax regime of Africa, but if introduced at the point of production by developing states, the development may encourage sustainable exploration of minerals in Africa in a manner that is environmental friendly and, thus, contribute to reducing activities which underlie emissions resulting into climate change and attaining economic development. This is an established point of discussion in the energy debate of developed nations. For instance, nations such as Finland and Sweden (Winkler and Marquard, 2011, pp. 90-92), Germany and the United Kingdom have introduced general energy taxes aimed at promoting energy efficiency and energy savings, thereby reducing GHG emissions (Owen and Ridge, 2011). Hence, the use of carbon tax as an instrument to achieve sustainable extraction is important in Africa, because it can be useful in provoking sustainable approach that reduces energy- and emissions-intensive mineral sectors of the economy and, therefore, protects the environment.

The introduction of green economy and carbon tax and their potential to enhance low carbon, reduce carbon emissions and pollution, in enhancing energy and resource efficiency, and prevent the loss 
of biodiversity and ecosystem services will not only improve the climate condition, it will boost a responsible approach by states toward their natural resources and, thus, have positive impact on the protection of the environment and the development of their economy. The basis for this reasoning rests in the fact that the global developmental pattern characterized by high carbon emission brought about the current state of the climate and unsustainable use of mining resources (Gorte and Sheikh, 2010). Hence, the prevention of the overuse of non-renewable natural resources which essentially form the extractive sector and the promotion of better management of natural resources will positively impact the environment and conserve resources for economic development not only for the present, but also the future generation. Initiatives such as REDD+ can remove or reduce pressures on natural ecosystems and species at risk in that they focus on risk assessment. In addition, sustainable projects under the CDM have immediate reward for the environment in that they aim at ending activities that pollute the environment, as well as encouraging other initiatives that regenerate the environment and preserve resources for sustainable economic development. Similar expectation can be made from initiatives such as the green economy and the implementation of carbon tax, which are premised on reducing the negative impact of extractive activities on the environment. It is safe to assume that such initiatives can contribute to the protection of the environment.

\section{Conclusions}

Academic analysis on climate change and the extractive sector has treated the subjects as though they were path independent. This paper sets out to explore the link of climate change to the extractive industry and the implication of the link for the protection of the environment and the economy in Africa. It established that the link between climate change and the extractive sector can be both negative and positive. Climate change can negatively impact the inputs of water and energy, people, supply chains, markets, exploration, construction, operation, closure, and post-closure aspects of the extractive sector in Africa. Also, as demonstrated in the paper, the nexus of climate change and the extractive industry can bring about environmental harm in that unsustainable extractive processes in terms of its outcome of deforestation and energy use are a significant source of carbon emission contributing to global warming.

The paper also established positive implication in the link in that relationship between the themes can stimulate initiatives that can contribute to sustainable extractive sector which enhances the economy and reduce emissions which contribute to climate change. Examples of these initiatives are projects under the CDM that advance reforestation and alternative sources of energies in developing countries and the REDD+ which aims at conservation of the forests. These projects can reduce reliance on the extractive sector and thereby guarantee the sustainable use which can positively impact on the environment and economic development. Other initiatives capable of similar implication for the extractive sector are the green economy, which enhances natural resource efficiency, and carbon tax which can address emissions associated with the extractive sector in Africa. In the light of the foregoing discussion, the link of climate change to extractive sector and its implications should be taken into consideration in the policy direction of states in Africa.

\section{References}

1. AfDB. (2008). Investing in Africa's future, Report of the High Level Panel, AfDB.

2. AfDB. (2013). Transitioning towards green growth: Stocktaking and the way forward, AfDB.

3. AfDB. (2014). West Africa Monitor Quarterly Issue 4, AfDB.

4. Aguado, A.Y. (2011). Climate change: Selected policy and legal issues for the extractive industry, International Energy Law and Policy Research Paper Series. Working Research Paper Series No: 2011/02.

5. Alton, T.A., Channing, R., Davies, F., Hartley, K., Makrelov, J., Thurlow and Ubogua, D. (2014). Introducing carbon taxes in South Africa, Applied Energy, 115, pp. 344-355.

6. Arent, D.J., Tol, R.S.J., Faust, E., Hella, J.P., Kumar, S., Strzepek, K.M., Tóth, F.L. and Yan, D. (2014). Key economic sectors and services, pp. 659-708. In Field, C.B., V.R. Barros, D.J. Dokken, K.J. Mach, M.D. Mastrandrea, T.E. Bilir, M. Chatterjee, K.L. Ebi, Y.O. Estrada, R.C. Genova, B. Girma, E.S. Kissel, A.N. Levy, S. MacCracken, P.R. Mastrandrea, and L.L. White (editors). Climate Change 2014: Impacts, Adaptation, and Vulnerability. Part A: Global and Sectoral Aspects. Contribution of Working Group II to the Fifth Assessment Report of the Intergovernmental Panel on Climate Change, Cambridge University Press, Cambridge.

7. Armah-Attoh, D. (2015). Ghana's oil revenue management: Convergence of popular opinion, the law, and practice, Afrobarometer Policy Paper No. 19.

8. Auty, R.M. (2002). Sustaining development in mineral economies. Routledge, London. 
9. Besada, H. (2013). Doing Business in Fragile States: The Private Sector, Natural Resources and Conflict in Africa. Background Research Paper. Available at: http://www.post2015hlp.org/wp-content/uploads/2013/06/Doing-Business-inFragile-States-The-Private-Sector-Natural-Resources-and-Conflict-in-Africa-FINAL-May-25-2013.pdf.

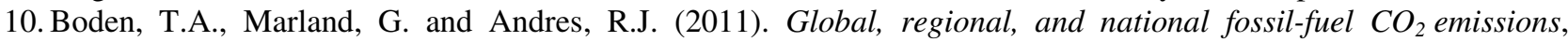
Carbon Dioxide Information Analysis Center, Oak Ridge National Laboratory, U.S. Department of Energy, Oak Ridge, Tenn., U.S.A.

11. Bowen, A. and Rydge, J. (2011). Climate change policy in the United Kingdom, Economics Department Working Papers No. 886, OECD.

12. Boyle, J., Cunningham, M. and Dekens, J. (2013). Climate Change Adaptation and Canadian Infrastructure A review of the literature, The International Institute for Sustainable Development, pp. 1-40.

13. Collier, P., Conway, G., Venables, T. (2008). Climate change and Africa, Oxford Review of Economic Policy, 24, pp. 337-353.

14. Cotula, L. (2012). The international political economy of the global land rush: A critical appraisal of trends, scale, geography and drivers, Journal of Peasant Studies, 39, pp. 649-680.

15. ECA. (2012). Green economy in the context of sustainable development and poverty eradication: What are the implications for Africa? ECA.

16. Faour, G., Mhawej, M. and Fayad, A. (2016). Detecting Changes in Vegetation Trends in the Middle East and North Africa (MENA) Region Using SPOT Vegetation. Available at: https://cybergeo.revues.org/27620\#quotation (accessed 18 October 2015).

17. Fischedick, M., Roy, J., Abdel-Aziz, A., Acquaye, A., Allwood, J.M., Ceron, J.-P., Geng, Y., Kheshgi, H., Lanza, A., Perczyk, D., Price, L., Santalla, E., Sheinbaum, C. and Tanaka, K. (2014). Industry, pp. 739-810. In O. Edenhofer, R. Pichs-Madruga, Y. Sokona, E. Farahani, S. Kadner, K. Seyboth, A. Adler, I. Baum, S. Brunner, P. Eickemeier, B. Kriemann, J. Savolainen, S. Schlömer, C. von Stechow, T. Zwickel and J.C. Minx (editors). Climate Change 2014: Mitigation of Climate Change. Contribution of Working Group III to the Fifth Assessment Report of the Intergovernmental Panel on Climate Change, Cambridge University Press, Cambridge.

18. Gore, A. (2006). An inconvenient truth: The planetary emergency of global warming and what we can do about it, Rodale, London.

19. Gorte, R.W. and Sheikh, P.A. (2010). Deforestation and climate change, CRS Report for Congress, USA.

20. Haberl, H., M. Fischer-Kowalski, F. Krausmann, J. Martinez-Alier, and V. Winiwarter (2011). A socio-metabolic transition towards sustainability? Challenges for another great transformation, Sustainable Development, 19, pp. 1-21.

21. Heinberg, R. (2015). Renewable Energy After COP21: Nine issues for climate leaders to think about on the journey home, Postcarbon, pp. 1-18. Available at: http://www.postcarbon.org/renewable-energy-after-cop21/(accessed 18 October 2016).

22. Helmut, J. and Lambin, E.F. (2001). What drives tropical deforestation: A meta-analysis of proximate and underlying causes of deforestation based on subnational case study evidence, Land-Use and Land-Cover Change (LUCC) Project IV.

23. Hirons, M., Hilson, G., Asase, A. and Hodson, M.E. (2014). Mining in a changing climate: What scope for forestrybased legacies? Journal of Cleaner Production, 84, pp. 430-438.

24. Hironsa, M. (2015). Trees for development? Articulating the ambiguities of power, authority and legitimacy in governing Ghana's mineral rich forests, The Extractive Industries and Society, 2, pp. 491-499.

25. Horsley, J., Prout, S., Tonts, M., Alib, S.H. (2015). Sustainable livelihoods and indicators for regional development in mining economies, The Extractive Industries and Society, 2, pp. 368-380.

26. UNFCCC CDM. Available at: http://cdm.unfccc.int/Projects/ (accessed 20 October 2016).

27. ICMM. (2012). Water management in mining: a selection of case studies, ICMM.

28. International Council of Mining and Metals (ICMM) (2013). Adapting to a changing climate: Implications for the mining and metals industry, ICMM.

29. IPCC. (2013). Summary for policymakers, pp. 3-29. In T.F. Stocker, D. Qin, G.-K. Plattner, M. Tignor, S.K. Allen, J. Boschung, A. Nauels, Y. Xia, V. Bex, and P.M. Midgley (editors). The physical science basis: Contribution of Working Group I to the 5th Assessment Report of the Intergovernmental Panel on Climate Change, Cambridge University Press, Cambridge.

30. Jegede, A.O. (2016). The climate change regulatory framework and indigenous peoples' lands in Africa: Human rights implications, Pretoria University Law Press, Pretoria.

31. Kelly, T.D. and Matos, G.R. (2013). Historical statistics for mineral and material commodities in the United States, US Geological Survey Data Series.

32. Kheshgi, H.S., S.J. Smith, J.A. Edmonds. (2005). Emissions and atmospheric CO2 stabilisation, Mitigation and Adaptation Strategies for Global Change, 10, pp. 213-220.

33. King, N. (2014). Southern Africa's dryland forests and climate change adaptation, Policy Briefing, 91, pp. 1-4.

34. Klein, R.J.T., S. Huq, F. Denton, T.E. Downing, R.G. Richels, J.B. Robinson and F.L. Toth (2007). Interrelationships between adaptation and mitigation, pp. 745-777. In M.L. Parry, O.F. Canziani, J.P. Palutikof, P.J. van der Linden and C.E. Hanson (editors), Climate Change 2007: Impacts, Adaptation and Vulnerability. Contribution 
of Working Group II to the Fourth Assessment Report of the Intergovernmental Panel on Climate Change, Cambridge University Press, Cambridge.

35. Kosoy, N., P.G. Brown, K. Bosselmann, A. Duraiappah, B.Mackey, J. Martinez-Alier, D. Rogers, and R. Thomson (2012). Pillars for a flourishing Earth: Planetary boundaries, economic growth delusion and green economy, Current Opinion in Environmental Sustainability, 4, pp. 74-79.

36. Locke, P., C. Clifton, S. Westra (2011). Extreme weather events and the mining industry, Engineering and Mining Journal, 212, pp. 58-59

37. Mailey, J.R. (2015). The anatomy of the resource curse: Predatory investment in Africa's extractive industries ACSS Special Report, A publication of the Africa Centre for Strategic Studies

38. Ndlovu, Z.S. (2016). Assessing whether rehabilitation programs from South African mining companies have considered the impacts of climate change. A Research Report submitted to the Faculty of Science, University of the Witwatersrand, Johannesburg, in partial fulfilment of the requirements for the degree of Master of Science.

39. Neingo, P.N., T. Tholana (2016). Trends in productivity in the South African gold mining industry, Journal of the Southern African Institute of Mining and Metallurgy, 116, pp. 283-290.

40. Nhamo, G. (2013). Green economy readiness in South Africa: A focus on the national sphere of government', International Journal of African Renaissance Studies, 8, pp. 115-142.

41. Niang, I., O.C. Ruppel, M.A. Abdrabo, A. Essel, C. Lennard, J. Padgham, and P. Urquhart (2014). Africa, pp. 1199-1265. In V.R. Barros, C.B. Field, D.J. Dokken, M.D. Mastrandrea, K.J. Mach, T.E. Bilir, M. Chatterjee, K.L. Ebi, Y.O. Estrada, R.C. Genova, B. Girma, E.S. Kissel, A.N. Levy, S. MacCracken, P.R. Mastrandrea and L.L.White (editors). Impacts, adaptation, and vulnerability: Regional aspects. Contribution of Working Group II to the Fifth Assessment Report of the Intergovernmental Panel on Climate Change, Cambridge University Press, Cambridge.

42. Nigeria: Africa's new number one, The Economist. 12 April 2014.

43. Nweke, O.C., and Sanders, W.I. (2009). Modern environmental health hazards: A public health issue of increasing significance in Africa, Environmental Health Perspectives, 117, pp. 863-870.

44. Oluduro, O. (2014). Oil exploitation and human rights violations in Nigeria's oil producing communities, Intersentia, Atwerp.

45. Pearce, T.D., J.D. Ford, J. Prno, F. Duerden, J. Pittman, M. Beaumier, L. Berrang-Ford and Smith, B. (2011). Climate change and mining in Canada, Mitigation and Adaptation Strategies for Global Change, 16, pp. $347-368$.

46. Perrot, R. (2012). The green economy in Africa: A critical overview. Available at: http://www.mistra.org.za/Media/Articles/Documents/The\%20Green\%20Economy\%20R\%20Perrot.pdf (accessed 15 October 2015).

47. Ranchod, N., Craig, M., Sheridan, C.M., Pint, N., Slatter, K., Harding, K.G. (2015). Assessing the blue-water footprint of an opencast platinum mine in South Africa, Water SA, 41, pp. 287-293.

48. Reyburn, R., Ryun Kim, Emch, M., Khatib, A., Seidlein, L. Von and Ali, M. (2011). Climate variability and the outbreaks of cholera in Zanzibar, East Africa: a time series analysis, American Journal of Tropical Medicine and Hygiene, 84, pp. 862-869.

49. Rudel, T.K. (2013).The national determinants of deforestation in sub-Saharan Africa, Philosophical Transactions of the Royal Society, pp. 1-7.

50. SASB (Sustainability Accounting Standards Board). (2014) Metals and Mining Research Brief. Available at: http://www.sasb.org/wpcontent/uploads/2014/06/NR0302_MetalsMining_2014_06_24_Industry_Brief.pdf. Accessed on 19 October 2016.

51. Sikamo, J., A. Mwanza, C. Mweemba. (2016). Copper mining in Zambia - history and future, Journal of the Southern African Institute of Mining and Metallurgy, 116, pp. 491-496.

52. Stevens, P., Lahn G. and Kooroshy J. (2015). The Resource Curse Revisited, Research Paper, Energy, Environment and Resources.

53. Tauli-Corpuz, V. and Lynge A. (2007). Impact of climate change mitigation measures on the territories and lands of indigenous peoples, E/2007/43 E/C.19/2007/12.

54. Toulmin, C. (2009). Climate change in Africa. Zed Books, London.

55. Ulrich, B. (2012). Green economy - the next oxymoron? No lessons learned from failures of implementing sustainable development, GAIA - Ecological Perspectives for Science and Society, 21, pp. 28-32.

56. UNCTAD. (2008). World Investment Report Transnational corporations and the infrastructure challenge, UNCTAD.

57. UNEP. (2011). Towards a Green Economy: Pathways to Sustainable Development and Poverty Eradication, UNEP.

58. UN-REDD. Partner countries. Available at: www.un-redd.org/Partner_Countries/tabid/102663/Default.aspx. (accessed 17 October 2016).

59. USAID. (2013). Policy Brief on the West Africa Coastal Climate Change National Adaptation Planning Workshop June 18-20, 2013, Accra, Ghana. Available at: https://www.usaid.gov/sites/default/files/documents/1860 /NAP\%20Policy\%20brief.pdf (accessed 20 October 2016).

60. Van der Ploeg, F. (2011). Natural resources: curse or blessing? Journal of Economic Literature, 49, pp. 366-420. 
61. Vermeulen, S. and Cotula L. (2010). Over the heads of local people: Consultation, consent, and recompense in large-scale land deals for biofuels projects in Africa, Journal of Peasant Studies, 37, pp. 899-916.

62. WHO. (2014). Chemicals of public health concern and their management in the African Region. Available at: http://apps.who.int/iris/bitstream/10665/178166/5/9789290232810.pdf?ua=1.

63. Willem den Besten, J., B. Arts, and P. Verkooijen. (2014). The evolution of REDD+: An analysis of discursiveinstitutional dynamics, Environmental Science and Policy, 35, pp. 40-48.

64. Winkler, H., and A. Marquard (2011). Analysis of the economic implications of a carbon tax, Journal of Energy in Southern Africa, 22, pp. 55-68.

65. WTO. (2010). Frequently Asked Questions: WTO compatibility of border trade measures for environmental protection, WTO.

66. Wunder, S. (2005). Oil wealth and the face of the forest: A comparative study of eight tropical countries, Routledge, London.

67. Yue-Jun, Z. and Yi-Ming ,W. (2010). An overview of current research on EU ETS: Evidence from its operating mechanism and economic effect, Applied Energy, 87, pp. 1804-1814. 